\title{
A Comparative Study of Arabic Motion Verbs to their English Counterparts
}

Dr. Mahmoud Mamdouh Baker Nassar ${ }^{1}{ }^{*}$, Akram Idrees Mohammad Al-Ashqar ${ }^{2}$ \& Mohammad Ali Abedalqader Shatanawi ${ }^{3}$

${ }^{1}$ Doctor, Ministry of Education, Jordan

${ }^{2}$ Instructor, Ministry of Education, Jordan

${ }^{3}$ Supervisor of English Program, Islamic Educational College, Jordan

Corresponding Author: Dr. Mahmoud Mamdouh Baker Nassar, E-mail: mahmoudnassarrj@yahoo.com

\section{ARTICLE INFORMATION}

Received: August 12, 2020

Accepted: September 28, 2020

Volume: 3

Issue: 9

DOI: $10.32996 / \mathrm{ijl} \mid \mathrm{t} .2020 .3 .9 .21$

\section{KEYWORDS}

Arabic, English, motion, semantics, verb

\section{ABSTRACT}

This paper examines some semantics aspects of Arabic motion verbs compared to their English counterparts. Although both languages belong to different remote families, both languages share some common features about Motion especially on the idea of locomotors vs. non-locomotors (translative and non-translative movement). A lexically-semantic comparison is drawn between motion verbs in both languages in terms of suggested semantic components such as Motion itself, Manner, Directionality, Path, Fictive, and Motion. The researchers used resources such as encyclopedias, library references books specially Mu'jam Lisan AL-Arab, AlMu'jam Al-Waseet, English dictionaries specially Oxford, Webster, and Longman, web sites to collect data of motion verbs under discussion. The paper concludes that the semantics components of Arabic verbs are quite similar to their English counterparts, but Arabic verbs differ greatly from English verbs in the notions that can be lexicalized.

\section{Introduction}

\subsection{Motion}

Motion is the real expression of life. Everything in life goes through motion and no events escape motion (Dawood 2012). Recently, the study of motion verbs has become the main concern of linguists in almost all languages of the world. In his study, Alonge (1991) concluded that motion verbs became the subject of several studies because they present interesting semantic characteristics. From a scientific point of view, the term motion involves a change in position. It first originated in physics as "a change in position of an object concerning time and its reference point" (Wikipedia). Soon, the term found its way to linguistics. Talmy (1985, p. 85) defines motion as "situations containing movement or the maintenance of a stationary location"

Frawley (1992) described motion verbs as a displacement of an entity. In Arabic, Al Mu'jam Al Wasset's definition of the word 'haraka' "الحركة" was not very far from this definition, if not the same "the displacement of something from one place to another". In general, Arab linguists agreed on Ibn Manzour's definition that the word motion is 'anti-statism'. For this study, the Arabic definition will be taken into consideration more than the English one because the latter definition focuses on displacement and change of state as the main feature of motion verbs. Later, it will be demonstrated that some motion verbs do not necessarily involve displacement or change of state.

\subsection{The Arabic Language and its Speakers}

Bishop (1998) described Arabic as one of the countless modern languages of the world. Arabic is a language spoken in the Middle East, North Africa and African Horn. It belongs to the Semitic family of languages along with other languages such as Hebrew and Amharic. Bishop adds that Arabic ranks sixth in the world's league table of languages, with an estimated 300 million- native speakers. As the language of the Qur'an, it is also widely used throughout the Muslim world. There are many Arabic dialects. Classical Arabic - the language of the Qur'an and Modern Standard Arabic which is used in books, newspapers, mass media, mosques, and conversations among educated Arabs from different countries. To understand

K C
R D AL-KINDI CENTER FOR RESEARCH AND Your gateway to world-class research
Published by Al-KindiCenter for Research and Development. Copyright (c) the author(s). This is an open access article under CC BY license (https://creativecommons.org/licenses/by/4.0/) 
Arabic words' spelling, it is necessary to have a quick look at the various phonological, morphological, and syntactic changes which together have created a unique dialectal Arabic situation.

\subsection{Motion and Semantic Classes}

Semantics is the study of different meanings. Verbs semantic classes are constructed from verbs that undergo a certain number of alternations. Most definitions of semantic classes agree that a semantic class contains words that share a general semantic property. The category of verbs was particularly chosen because most linguists agree that verbs, in most languages, are the most spread and widely-used category of speech. They are the most important constituents of sentences. Talmy (1985) states that categorizing verbs into semantic classes that share similar features aims mainly to find meaning components forming the semantics of verbs, the specification of more subtle meaning elements that distinguish closely related verbs, and the study of the cooperation between syntax and semantics. In his work on verb classes, Fillmore (1979) states that verb classes are a useful device for reviewing the semantic organization of the verb lexicon. He discusses how the semantic properties of the verb shake differ from those of the verb shudder.

a. She shook. / shook her.

b. She shuddered. /*I shuddered her.

He explained that (1) things that shudder are people, animals, earth, machines/engines that have 'self-controlled bodies'. Shake denotes an event that can be 'externally caused'. (2). Things that shake are the above and leaves, furniture, dishes. Shudder denotes an event that is 'internally caused'.

Later, linguists began to classify motion verbs according to semantic components that contain a variety of lexicalization. The following lexicalization, for example, walk, run, stalk, jog, hurtle, and march belongs to the semantic component of movement. Within the group, semantic features entitle a particular verb to be suitable for a particular situation and another to be suitable for other situations and so on. For example:

run 'move at a speed faster than walk'.

walk 'move at a regular pace'.

jog 'to run slower than running'.

march 'related to military'.

The same subject is present in the Arabic language. According to Dawood(2012), the following lexicalization masha מشى,

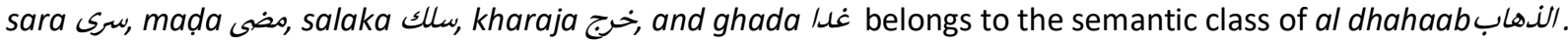

They all encode movement in all directions towards a specific goal, but they differ lexically according to a set of factors. For example, speed, force, time of the day, and so on.

- Sara ى $ى$ expresses obligation and related to a specific time of the day (night) and the specific destination.

- masha مشى is voluntary and not necessarily towards a goal.

- mada مضى is quicker than sara wa and masha مشى

Motion is central to the human experience. It seems to be a universal concept present in all the languages of the world. Languages encode motion in different ways. Since the appearance of Talmy's typology of motion verbs, many non-English linguists carried out studies(1) to certify whether their languages satisfy Talmy's typology or not and (2) to draw a comparison with the English language to indicate where the two languages meet and where they differ in terms of expressing motion.

According to Talmy, all Germanic languages are satellite-framed languages. On the other hand, all Romance languages and some non-Romance languages, including Arabic, are verb-framed. A satellite-framed language expresses the core component of motion, Path, for example, in satellites (e.g., up, down) or in prepositional phrases (e.g., into/out of the house), leaving the verb slot free to encode the manner-of-motion. A verb-framed language typically expresses path in the main verb while relegating the expression of manner to adjuncts e.g. dakhala/kharadza jaryan enter/exit running. Talmy's argumentation extends to classifying motion verbs according to primary semantic components such as (Motion, Manner, Direction, Goal, Source, Path, Medium, and Purpose). 
This paper, while discussing Talmy's typology, aims to provide a systematic and detailed account of the semantics of some Arabic motion verbs and compare them to their English counterparts. As claimed, a better understanding of the semantics of motion verbs in these two languages is of primary importance for cross-linguistic research on motion event descriptions.

The primary goal of this work is to provide a comparative account of the semantics of a substantial part of the Arabic motion verb lexicons, focusing specifically on Talmy's general semantic components for the motion: (Motion (Space), Direction, Manner, Path, and Environment). For that purpose, several fine-grained motion verbs which have been widely used in everyday speech, have been discussed. On the whole, this paper seeks to provide answers to the following general research questions:

1. What are the semantic properties of Arabic motion verbs?

2. Does Arabic have a motion verbs lexicon that is comparable to their English counterparts?

\subsection{Locomotors and Non-Locomotors}

Locomotors motion verbs require the movement from one place to another (displacement) as in the verbs taharraka تحرك ,

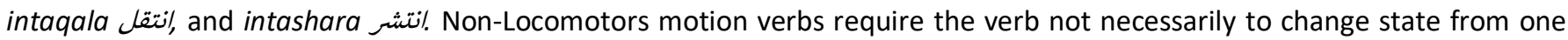
position to another as in the verbs daqqa دقن and khabața Along the same line, Talmy (1985:141) states that "translative movement involves the movement through space of the entire theme, or entity in motion, and results in a change of location of the theme. Nontranslative movement involves body-internal movement, periodic or random movement, or movement through space of a part of the theme but not the entire theme". Some of the widely-spread locomotors and non-locomotors verbs in Arabic include:

\begin{tabular}{|c|c|c|c|}
\hline \multicolumn{2}{|c|}{ Locomotors } & \multicolumn{2}{|c|}{ Non-locomotors } \\
\hline IPA spelling & English counterpart & IPA spelling & English counterpart \\
\hline انتقل intaqala & Transfer & خبط khabața & hit \\
\hline taharraka تحركt & Move & دقdaqqa & knock \\
\hline انتشرintashara & spread & صدم șadama & collide \\
\hline
\end{tabular}

\section{Literature review}

Talmy (1985) states that semantic features that distinguish motion verbs classes are the moving entity (Figure), the landscape against which it moves(Ground), the Motion itself, the path along which it moves, and the Manner of its movement (running, sliding, bouncing, etc.). For example: 'Ali ran to school' where Ali represents the Figure, the school represents the Ground, to expresses the Path, and ran represents the Motion and Manner.

Talmy (1985) claims that languages according to verb roots with relation to the expression of 'Motion' are classified into two types: Verb-framing describes the path which refers to the direction of the movement, e.g., movement across, into, out of, etc. The direction of the verb is expressed in the root verb itself. The manner is expressed independently. These types include Romance, Semitic and Polynesian ones. Satellite-framing describes the manner of motion which expresses motion using a particular verb (satellite such as from, away, to......). They encode Path in a satellite (that is, a verbal dependent). This type includes English, some other Indo-European languages, and Chinese.

Later, Levin (1993) discussed how the semantics of path verbs differ from the semantics of manner verbs depending on Talmy's theory who cited (Kudrnáčová 2008: 35), saying that "Path verbs cannot encode motion as translocation by themselves". To do so, they need grounding. For example, a moving entity cannot just come, but must come to /out to a certain place. The same is done with the verb leave which must leave a place. Levin classified the directionality of verbs into five categories. The largest of those was the manner of motion in which he distinguishes two- subtitles (1) Roll verbs and (2) Run verbs. The Roll verbs were characterized by the semantic feature of inanimate (bounce, drift, drop, float, glide, move, roll, slide and swing). Run verbs describe how animated entities can move (skip, sweep, swim, travel, climb, drift, file, flit, and float). Levin argued how to discover meanings of verbs. One of her arguments was "the Foundational Assumption: Verb 
Meaning Provides a Key to Verb Behavior". She supported her claim with the English denominal verbs and provided a case study of texting and faxing:

He texted/faxed the answer/ the librarian wanded the barcode.

Double-object construction: He texted/faxed me the answer/ *the librarian wanded me the barcode. Levin explained that text and fax are verbs of information transfer, while wand is not a verb of information transfer.

A second case study is Fillmore's (1970) well-known study, "The Grammar of Hit and Break which shows how examining verb behavior can provide insight into verb meaning via a case study of two verbs. Some of his different realizations of these two verbs were:
a. The boy broke the window with a ball.
b. The boy hit the window with a ball.
c. The boy broke the window.
d. The window broke.
e. The boy hit the window.
f. The window hit.
g. The window was broken.
h. The window was hit.

Fillmore answered the questions of why the divergences take the forms that they do by saying that the verbs break and hit are each representatives of a larger semantically identifiable class of verbs. The Break Verbs: bend, fold, shatter, and crack are verbs of change of state. The Hit Verbs: slap, strike, bump, stroke are verbs of surface contact. Fillmore concluded that the fact that classes of verbs with similar meanings show characteristic argument realization patterns which suggests that the patterns can be attributed to facets of meaning common to class members. Fillmore's case study shows how semantic and syntactic properties of a verb are not idiosyncratic but may be attributed to an entire class.

Matched and Paykin (2016) claim that weather verbs can be considered as motion verbs, although with a very dissimilar behavior according to the presence of the conceptual components figure and path. If 'rain' involves one single figure and path, other weather verbs may or may not involve some or none. However, they consistently express manner, both in atmospheric and metaphorical contexts express directional motion.

Barlew (2017) concluded that come and $z u$ 'come' requires the retrieval of a contextually supplied perspective, a body of knowledge that represents the way a particular individual imagines things to be. For come and $z u$ to be used acceptably, it must be true, according to the retrieved perspective, that the individual is located at the destination of motion event being described. If the individual does not self-ascribed being located at the destination, then neither come nor zu can be used.

In his extensive study of the transitional motion verbs in the Noble Qur'an, Shalaby (2010) depends on Arabic famous Ma'ajim and Al Tafaseer books to deduce the semantic properties of each verb. His study was to put verbs that share common characteristics into semantic classes, then to tackle each verb separately, and finally to discuss the entire class as a whole. He discusses thoroughly why, in the Noble Qur'an, $\underline{a} r s a l a d$ is used in a certain context with prophets and why

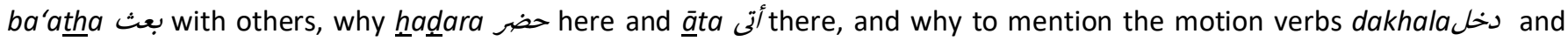
dhahaba ذهب for 109 and 44 times, respectively.

Shalaby classified his work into three chapters. The first one included classifying verbs that share similar semantic properties into classes, and then to discuss each verb according to specific factors such as the force that causes movement and speed of the action. For example, the semantic properties of masha مشى indicate that it is voluntary but the semantic properties of inșarafa نصرف indicate that it is compulsory. Speed is apparent in the verb rakada رشض, whereas speed in other verbs is determined according to situation. For example, the verb raja'a رجع can carry the feature of quickness or slowness according to the situation.

Dawood (2012) went further in defining motion verbs as the real expression of life. He also objected to translating the following English terms of motion, movement, action, and motor into one Arabic term as haraka. The most relevant and suitable English and Arabic counterparts are (motion vs. haraka), respectively because both terms in both languages are the most common and comprehensive than any other terms. Moreover, Dawood explained that motion verbs need five factors: the time they take, the place where they occur, the force needed for them, the source of such verbs, and the environment accompanying them. He discussed three main issues related to classifying motion verbs. The first one is the dilemma of ' which is a verb of motion and which isn't? The second one has to do with how common and frequent a motion verb is being 
used in the language of a specific era. Language is always changing and developing. If a certain verb is rarely or widely used in the contexts of time, this indicates that the linguistic society of the time is abdicating or approving such a verb and thus can or cannot be counted upon. The third issue is that classifying motion verbs of a language remains a point of view after all. It is controlled by different considerations: alphabetical, developmental, historical, or in terms of meanings. Overlapping between the fields permits a verb to be a member of more than one field and many other sub-fields.

\section{Data collection}

A deep study will be carried out on the target verbs. The researchers used resources such as encyclopedias, library references books specially Mu'jam Lisan AL-Arab, Al-Mu'jam Al-Waseet, English dictionaries specially Oxford, Webster, and Longman, web sites to collect data of motion verbs under discussion.

\section{Data analysis}

\subsection{Semantic Components of Arabic Motion Verbs}

In general, most Arabic motion verbs seem to fall into the main component of Direction. For demonstration, representative verbs of each component are discussed to show how the groups work.

\subsection{Direction of Motion (Movement)}

The direction is divided into three groups: (1) horizontal movement which in turn is divided into two subgroups: leaving and arrival, (2) vertical movement which in turn is divided into two subgroups: ascending and descending (up and down) and (3) circular movement.

\subsubsection{Horizontal Movement}

4.2.1.1 Motion Verbs of Leaving (Departure)

Some of the verbs of this group include:

\begin{tabular}{|c|c|}
\hline Spelling & Arabic spelling \\
\hline kharaja & خرج \\
\hline dhahaba & ذهب \\
\hline raḥala & رحل \\
\hline raḥa & راح \\
\hline safara & سافر \\
\hline inșarafa & انصرف \\
\hline ghadara & غادر \\
\hline maḍa & مضى \\
\hline haajara & هاجر \\
\hline
\end{tabular}

All these verbs indicate leaving a place to another. For the first sight, the whole content might seem the same. kharajaج $خ$ is

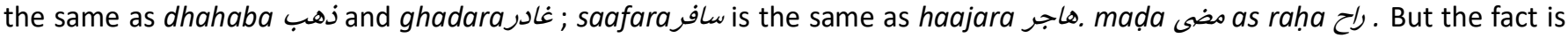
that they differ in specific features such as the importance of the place being left, whether leaving happens voluntarily or willingly, distance, the period of leaving, and so on.

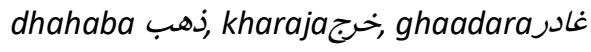

ذهب

According to Shalaby (2010), this motion verb is mentioned in the Noble Qur'an 44 times because of the various semantic properties it has. The most important one is (+purpose) because someone goes somewhere for a goal and a purpose. It might happen willingly or voluntarily. It might be quick or slow depending on the context. Al Mu'jam Al Wasseet mentions the following main usages of this motion verb. 
- general meaning: going somewhere

dhahaba ālțalibu ila ālmadrasati

ذهب الطالب إلى المدرسة

- $\quad$ vanishing and ending

dhahaba allaahu binurihim

$$
\text { ذهب الله بنورهم }
$$

- $\quad$ an endpoint of thinking

dhahaba bikhayalihi ba'idan

$$
\text { ذهب بخياله بعيدا }
$$

غادر ghadara

This verb has the same property of leaving a place to another one. It differs by indicating the far distance and the importance of the place being left.

- leaving a place and going away

ghaadara fariquna ālwațani ila baghdad

$$
\text { غادرفريقنا الوطني إلى بغداد }
$$

خرج kharaja

This verb has also the property of leaving, but from some kind of a narrow space into a wider one. It is distinguished by its wide variety of semantic features. The agent might be animate or inanimate. It might be quick or slow. Shalaby (2010) counted 137 occurrences of kharaja in the Noble Qur'an.

- Go from .....to

kharaja min ālbayti ila ālhadiqati

$$
\text { خرج من البيت الى الحديقة }
$$

\section{- change and transformation}

ātamanna ān nakharuja min ḥalati ālrukud āliqtiṣadi

$$
\text { اتمنى ان نخرج من حالة الركود الاقتصادي }
$$

- from silence to speech

ma kharaja min fami harfun waḥidun

$$
\text { ما خرج من فمي حرف واحد }
$$

\begin{tabular}{|c|c|}
\hline Spelling & Arabic spelling \\
\hline ātaa & اتى \\
\hline jaa'a & جاء \\
\hline ḥaḍara & حضر \\
\hline dakhala & دخل \\
\hline dana & دنا \\
\hline raja'a & رجع \\
\hline ‘ada & عاد \\
\hline aqbala & اقبل \\
\hline iqtaraba & اقترب \\
\hline
\end{tabular}

- refusal and denial

kharaja 'an ra'i āljama'ati

خرج عن راي الجماعة

\subsubsection{Motion Verbs of Arrival}

Some of the verbs of this group include: 


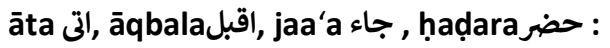

These verbs share the characteristics of moving forward to achieve a specific goal. The one who is coming knows exactly where to come and why. He/she does so willingly without fear. Most of such verbs were related to prophets in the Noble Qur'an because prophets know where to go and why (delivering a message) without fear or obligation (Shalaby 2010). These verbs nearly have the same meaning. Semantically, they differ according to context.

àtaa 1

$\overline{a t a a}$ is used to indicate a forward movement to achieve a specific goal willingly. That is why this verb is used in some verses of the Noble Qur'an with prophets because prophets were sent willingly to deliver a specific message. The motion might be performed quickly or slowly, by animates and inanimates.

- $\quad$ pass by

ātaa 'ala qawmin

اتى على قوم

- become too close

àtat sa'atuhu

أتت ساعتُه

- annihilate and destroy

ātaa 'ala ālākhḍri wa ālyabisi

الى على الأخضر واليابس

āqbala

$\bar{a} q b a l a$ has the same semantic properties as ātaa except that it is (+animate). It was never mentioned in the Noble Qur'an with inanimate although Arabic dictionaries do classify it as (+/-animate). Some of the semantic uses of this verb are:

- $\quad$ imminent/ happening soon

āqbala ālșabaḥu

اقبل الصباح/ اقبل العيد

- $\quad$ energy and activity

āqbala "la āldarsi bihimatin

اقبل على الدرس بهمة

- $\quad$ production and fruitfulness

āqbalat ālarḍu bilnabati

اقبلت الارض بالنبات

- livelihood and open-handedness

āqbalat 'alayhi āldunia

اقبلت عليه الدنيا

jaa'a جاء

$j a a^{\prime} a$ ج is specially related to prophets bringing their evidence and proofs to convince people with religions of Allah, to motivate them to do the righteous deeds and to show the powers of Allah, the Almighty. Shalaby (2010) counted 260 occurrences of this verb in the Noble Qur'an. Al Mu'jam Al Wasseet and Al Mu'jam Al Muheet agree on the following semantic meanings of this verb:

- came down to earth

jaa'a āl ghaythu

جاء الغيث

- arrived

jaa'a ālkhabaru āssar

جاء الخبر السار

- taking place/ occurring

jaa'a nașru āllahi

جاء نصر الله 
- printed and published

jaa'a fi ālșuḥfi

حضر حضر hadara

جاءَ في الصُحف

haḍara indicates a forward movement that might be willingly or voluntarily, quickly or slowly.

- $\quad$ attended

ḥaḍara darsa ālāmsi

حضر درس الامس

- $\quad$ time for something

hadarat ālșalata

حضرت الصلاة

- $\quad$ remember/come to the mind

haḍarahu baytu ālsh'ri

حضره بيت الشعر

- $\quad$ strike/ hit

hadạara fulanan ālmawut

حضرفلانا الموت

4.2.2. Vertical Movement

4.2.2.1 Motion Verbs of Ascending

Some of the verbs of this group include:

\begin{tabular}{|c|c|}
\hline Spelling & Arabic spelling \\
\hline ḥamala & حمل \\
\hline rafa'a & رفع \\
\hline irtaqa & ارتقى \\
\hline tasallaqa & تسلق \\
\hline șa'ada & صعد \\
\hline
\end{tabular}

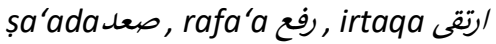

The main semantic properties of this group are: (+motion + moving upward). The frequency of usage depends on the status of the person. For example, rafa'a is mentioned in the Noble Qur'an more than șa'ada because of the superior status that Allah promised believers with.

șa'ada

This verb requires an effort to reach a high place gradually. It might happen willingly or voluntarily. Speed is slow because it is done carefully to reach a specific goal safely. The direction also plays a part in determining the meaning of this verb.

- common meaning: going upward

șa'ada āl imamu 'ala ālminbari

صعد الامام على المنبر

- superiority and fame

șa'ada āl najmu sullama ālshuhrati

صعد النجم سلم الشهرة

- $\quad$ increase and abundance

tatașa'adu ālanashidu min afwahi ālțalabah

تتصاعد الاناشيد من افواه الطلبة

rafa'a رفع

This verb, when relates to animate, is voluntary because Allah is alrafi'. Speed tends to be slow since quickness might cause damage to the one being pulled up. 
- common meaning: moving upward

rafa'a ālțalibu yadahu

رفع الطالب يله

- displacement / removing

rafa'a āl'amilu ālșakhrata 'an ālarḍi

فع العامل الصخرة عن الارض

- an endpoint of something

rafa'at ālduwalu ālhadhra 'an āl'iraq

رفعت الدول الحظر عن العراق

- political connotations

rafa'a shi'ar

رفع راية كنا / رفع شعاركنا

- dignity and grace

rafa'tum āljibaaha 'alyan

رفتم الجباه عاليا

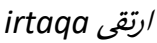

- $\quad$ sit on throne

irtaqa āl maliku 'ala 'arshi

ارتقى الملك العرش

- promotion

irtaqa fi ālwadhifati

ارتقى في الوظيفة

\subsubsection{Motion Verbs of Descending}

Some of the verbs of this group include:

\begin{tabular}{|c|c|}
\hline Spelling & Arabic spelling \\
\hline inḥdara & انحدر \\
\hline saqața & هبط \\
\hline sakaba & سكب \\
\hline habața & \\
\hline
\end{tabular}

سقط هبط saqata

هبط

This verb indicates descending from a higher place to a lower one. It usually happens willingly. It is done quickly, but carefully.

- Common meaning: coming downward

habațat ālța'ratu

هبطت الطائرة

- imminent

habața āl dhalamu sarii'an

هبط الظلام سريعا

- decrease and diminution

habațat sha'biat ālra'ees ila ālhaḍiḍi

هبطت شعبية الرئيس إلى الحضيض 
- descendence and declination

habațat ākhlaqu ālnasi

هبطت أخلاق الناس

saqața سقط

This verb indicates falling heavily. Direction plays a central part in determining the meaning of this verb. It usually happens unwillingly.

- common meaning: falling helplessly

saqața ālrajulu 'ajizan

سقط الرجل عاجزا

- demolition

yjawma saqata jidaru barliin

يوم سقط جدار بلين

\subsubsection{Circular Movement}

Some of the verbs of this group include:

\begin{tabular}{|c|c|}
\hline IPA spelling & Arabic spelling \\
\hline dara & دار \\
\hline laffa & لف \\
\hline țaafa & دحرama \\
\hline daḥraja & \\
\hline
\end{tabular}

لف daara, tafafa lafa

These verbs share the feature of a circular movement. They differ according to how complete the circle of movement is. Some of them do not require the agent to perform a closed circle while moving. Others are obligatory in some religious rituals and so cannot be replaceable.

daraj

Movement in this verb is circular in a closed circle. Its environment might be water or air. The agent might be animate or inanimate. The movement might be willing without external force or voluntarily with an external one.

- general meaning: movement in a circle

taduuru āl'ajalatu

تلدور العجلة

- turning around ( not necessarily in a circle and according to the thing being turned around)

daara ḥawla ālsayyarti

دارحول السيارة

- turning into another direction

ādara wajhahu wa maḍa fi țariqihi

ادروجهه ومضى في طريقه

- violence and severe war

daarat yawma āms ā'nafu ālma'arik

دارت يوم /مس /عنف المعارك

- disorder and nervousness

darat bihi āldunia

دارت به الدنيا

- leadership

ādara āldaktur halaqata ālniqash

ادار الكتور حلقة النقاش

- lack of care and interest 
ādara ālnaābu dhahrahu linaasi

ادار النائب ظهره للناس

- $\quad$ suspicion

yaduru hawla hadha ālrajlu shubuhatin kathiratin

يدورحول هذا الرجل شبهات كثية

taaffa طاف

This verb has strong religious indications with atțawaf around the Holy Ka'ba in Mecca. A Muslim starts from a specific point at Al hajar Alaswad (the black stone) on the right side of the Ka'ba and ends țawaf at the same starting point.

- moving to start and ending at the same point

țaafa ālmuslimuuna ḥawla ālka'bati

طاف المسلمون حول الكعبة

- $\quad$ passing on places of the same kind at the same time.

țuftu fi maḥali Irbid ābḥathu 'an kutub

طفت في محال /ريب /بحث عن كتب

- $\quad$ remembering and thinking about it.

țafat fi ra'si afkarun 'adiida

طافت في راسي افكر عديدة

laffacisan

Lisan Al Arab defines this verb as surrounding something with something else. The movement might be in a complete or incomplete circle. The verb has recently found its way into sports/games.

- general meaning: movement of something around something else.

ākhadhtu āluffu wa āduru hawla nuqțati ālhirasati

اخذت الف و ادورحول نقطة الحراسة

- meeting and gathering around someone or something

iltaffa ālțalabatu ḥawla ustadhahim

التف الطلبة حول استاذهم

- covering/ wrapping

laffa ālțabiibu raāsa ālmariị̣i

لف الطبيب راس المريض

- $\quad$ smooth movement at sports

yaluffu ālla'ibu wa yaduru fi ālmal'ab

يلف اللاعب ويدورفي الملعب

- $\quad$ encouragement and support.

iltaffat hawlahu āljamahiir

التفت حوله الجماهير

- deception and cunning

ilatffa hawla ālsu'ali

التف حول السؤال

\section{The Semantics of Motion Verbs in Arabic and English}

The semantic properties of English motion verbs are complex and display several levels of organization (Kudrnáčová.2008: 1). Like English, it seems that motion verbs in Arabic are also complex and display several levels of the organization. Motion verbs in Arabic may be grouped into components that are similar to those Talmy set in the year 1985, Theme (location), Figure, Ground, Path, and Manner. The most important is the direction. The semantic component' Direction of Motion' is present in both languages. In English, for example, we have "verbs of inherently directed motion" (Levin and Rappaport Hovav 1992) because they carry a specification of the direction of motion once they are uttered. He entered, he walked, he came, and he arrived. Levin also states that "semantically, these verbs always describe an entity's movement to an endpoint". 
All verbs in this class are (+ motion + directional). The Arabic language is not different in this respect. Arabic does have inherently directed motion verbs once they are uttered such as dakhala دخل, wașala وصل, and kharaja خرل. The subcategories of this component can be found in both languages.

English and Arabic have subclasses depending on the direction of motion along a given path (forward/backward on the horizontal axis as is the case for (advance/ retreat) upward/downward on a vertical axis, for (ascend/ descend), or no direction at all (arrive/reach), and circular movement).

In the following examples, each of Dragan's and Levin's classes of directed motion is accompanied by the Arabic counterparts from Shalaby's and ma'jim's classifications.

-forward: advance, cross, forge, penetrate, proceed.

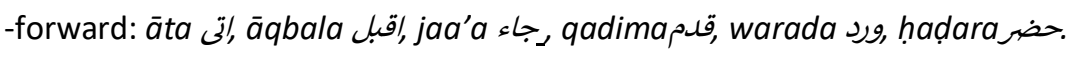

The Merriam Webster's School Dictionary differentiates members of the English group in the following way. Advance is to move forward; Proceed is to continue after a pause or interruption; the cross is to go from one side to the other; forge is to move steadily but gradually; penetrate is to pass into or through. So elements of the context such as speed, agent, and force determine the correct verb to be chosen. Shalaby (2010) differentiates members of the Arabic group as having the characteristics of moving forward to achieve a specific goal. āta is( -/+animate) while āqbala is (+animate); ja'a is(-/+ willingly); hadara (+continuous attendance)

-backward: rear, recede, retreat, return.

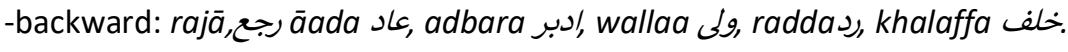

All these verbs have in common the feature of turning backward for a specific purpose whether willingly or unwillingly. The speed of action is determined according to the situation. For example, the Webster's Dictionary of Synonyms and Antonyms gives retreat and recede (+ voluntary) because they mean withdrawal from a point or position under pressure, while the return is (+/- voluntary). In Arabic, Shalaby demonstrates that adbara ولى have the feature (+voluntary) and

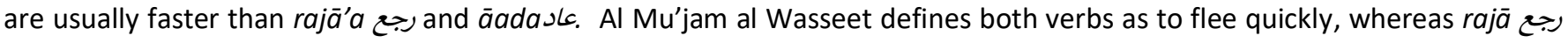
and āadase are (+/- voluntary).

-upward: arise, ascend, climb, rise, lift, and mount.

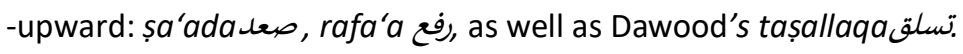

In English, and according to Webster's Dictionary of Synonyms and Antonyms, ascend implies progressive upward movement, and the Oxford Dictionary relates it to royal figures 'ascend the throne'. The Arabic irtaqa has the property of progressive upward movement because it also has to do with royals and promotions irtaqa āl maliku 'ala 'arshi. Mount suggests getting up upon something raised (a ladder according to the Oxford dictionary or a platform according to the Webster dictionary). In Arabic, the same semantic properties are present in șa'ada which requires an effort to reach a high place step by step șa'ida $\bar{a}$ imamu "la âlminbari. Climb connotes the effort involved in the upward movement (a tree, rope, wall, and mountain) and is used when difficulty is implicit in the situation. In the Arabic counterpart, Dawood explained that acting tașallaqa has the properties of difficulty, strength, and patience. tasallaqa älrajulu ālshajarata.

-downward: collapse, descend, crumble, drop, and fall.

-downward: habața هبط, saqața نسطدر inhadara

Collapse in English has the meaning of to break down and crash as in the example the Roman Empire collapsed. Arabic has the same property for the counterpart saqata as in the example yawma saqața jidaru barliin. The semantic meaning of collapse-to break down physically or mentally through exhaustion or disease- in both languages is the same: saqața a älrajulu 'ajizan and your health may collapse of working too hard. The counterpart verbs fall / habața have the same idea. Fall has the property or come to a lower level or point her spirits fell at the bad news. habața has the property of diminution

habațat sha'biat ālra'ees ila ālhaḍiḍi

-circular: spin, wrap, roll, twist, , whirl.

-circular: daraرد, țafa bاف, laffa. 
Spin has the property of rapid rotation; an excursion in a vehicle especially on wheels. dara has the same property of movement in a circle taduuru äl'ajalatu. wrap/laffa, in both languages, is to cover especially by winding or folding wrap a baby in blanket'/ 'laffa ālțabiibu raāsa ālmariiḍi.

To summarize, in both languages, motion verbs that share particular semantic features are grouped into semantic components. Grouping a set of verbs under one component does not mean that these verbs are synonyms. The slightest semantic property, for example (slow/quick), makes a difference.

\section{Conclusion}

The primary goal of this work is to provide a comparative account of the semantics of a substantial part of the Arabic motion verb lexicons, focusing specifically on Talmy's general semantic components for motion. This study of some motion verbs in Arabic revealed many interesting facts.

1. Arabic motion verbs are rich with sense relations:

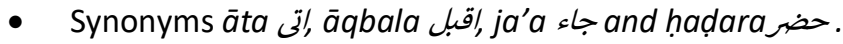

- Antonyms șa'adadeص, habața هب

- Metaphor دارت به الد

2. Some motion verbs are rarely used because they are related to specific time, place, and religious rituals or all together such as sarassw and țafa bاف.

3. Arabic prefers verbs with specific directions: horizontal, vertical, circular, and so on. Verbs that express random direction are rare in Arabic.

English is a Germanic language. Arabic is a Semitic one. This means that both languages belong to two different remote language families. Despite this fact, the two languages show no big differences in the way they express motion. Both languages admit the semantic components according to which motion verbs are classified: Motion; Direction; Manner; Path and Environment. Both languages contain pairs of Locomotors verbs which require the verb to change the place from one point to another such as in go/ kharaja $خ$ and Non-Locomotors verbs which require the verb not to change the place from one point to another and to move around the spot such as kneel/ raka'a ركع. Both have motion verbs of the component

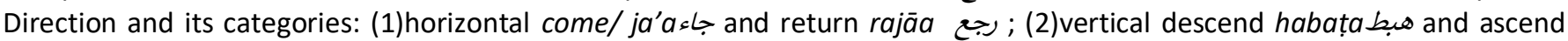
rafa'a נفקج); and(3) circular roll dahrajajally, both languages express path using particles. They differ in that in Arabic, an additional element is needed to show how the action is carried such as in dakhala jarian دحرل جريا. Although each group is categorized under one title, they are not synonyms. The choice of the adequate verb depends on the semantic properties, even if slight, of such a verb. Further studies can investigate motion verbs in religious books such as the Noble Qur'an and the Holy Bible.

\section{English References}

[1] Alonge, D.O. (1991). Textbook of Meat Hygiene in the Tropics. Ibadan, Nigeria: Farm Coe Press.

[2] Bishop, B. (1998). A history of the Arabic language. Department of Linguistics, Brigham Young University.

[3] Barlew, J. (2017). The semantics and pragmatics of perspectival expressions in English and Bulu: The case of deictic motion verbs (Doctoral dissertation, The Ohio State University).

[4] Fillmore, C.J. (1977). The case for case reopened. In P. Cole and J.M. Sadock, (ed.), Syntax and Semantics 8: Grammatical Relations Academic. 81-59. New York: New York Press.

[5] Fillmore, C.J. (1971). Types of Lexical Information. In D. Steinberg and L. Jakobovits, (ed.), Semantics, 370-392. Cambridge: Cambridge University Press.

[6] Frawley, W. (1992). Linguistic Semantics. Hillsdale, NJ: Lawrence Erlbaum.

[7] Kudrnáčová, N. (2003). External temporal specification in English verbs of motion. Theory and Practice in English Studies, 1, 53-58.

[8] Vogel, R. (2011). Kudrnáčová, N.(2008) Directed Motion at the Syntax-Semantics Interface. Discourse and Interaction, 4(2), 97-99.

[9] Levin, Beth (1993). English verb classes and alternations. Chicago: University of Chicago Press.

[10] Levin, B. and Rappaport Hovav. (1992). The Lexical Semantics of Verbs of Motion: The Perspective from Unaccusativity. In Roca, I. M. (ed.), Thematic Structure: It's Role in Grammar, 247-269. Berlin and New York: Foris Publications.

[11] Matched, Meullen and Katia Paykin. (2016). Weather verbs sifted through a motion sieve. Сопоставительная лингвистика, 5: 5867 
[12] Talmy, L. (1983). How language structures space. In H. L. Pick, Jr. and L.P. Acredolo (Ed.). Spatial Orientation: Theory, Research, and Application, 225-282. New York: Plenum.

[13] Talmy, L. (1985). Lexicalization patterns: Semantic structure in lexical forms. In Shopen, T, Language Typology and Syntactic Description, vol. 3: Grammatical Categories and the Lexicon (ed.), 57-149. Cambridge: Cambridge University Press.

[14] Talmy, L. (2001) Toward a Cognitive Semantics. Cambridge, Mass: MIT Press.

[15] The Oxford Advanced Learner's Dictionary, $4^{\text {th }}$ Edition. (1989). Oxford University Press.

[16] Webster's Dictionary of Synonyms and Antonyms, $4^{\text {th }}$ edition. (1996). Merriam Webster Inc.

[17] Webster's School Dictionary. (1986). Merriam Webster Inc.

[18] Wikipedia. (n.d.). https://en.wikipedia.org/wiki/Motion (retrieved on 20, October 2017)

[19]

\title{
Arabic References
}

\author{
[1] ابن منظور.(1993). لسان العرب .بيروت: التراث العربي.

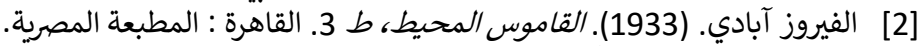

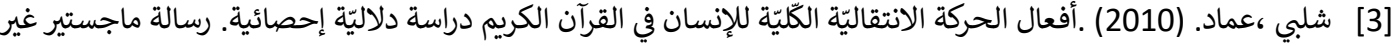

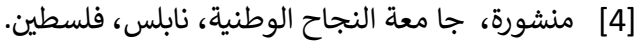

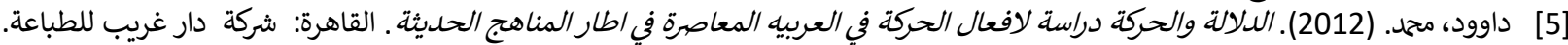

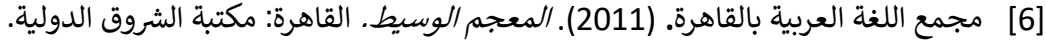

